\title{
Home Environment and Emergent Literacy among Young Children in Iran
}

\author{
Azimeh Jafari Sadr ${ }^{1}$, Rumaya Juhari ${ }^{2}$, Mariani Mansor ${ }^{2} \&$ Nooshin Sabour Esmaeili ${ }^{3}$ \\ ${ }^{1}$ Department of Human Development and Family Studies, Faculty of Human Ecology, Universiti Putra Malaysia, \\ Malaysia \\ ${ }^{2}$ Family, Adolescent and Child Research Excellent Centre (FACE), Faculty of Human Ecology, Universiti Putra \\ Malaysia, Malaysia \\ ${ }^{3}$ Department of Psychology, University of Fribourg, Switzerland \\ Correspondence: Azimeh Jafari Sadr, Department of Human Development and Family Studies, Faculty of \\ Human Ecology, Universiti Putra Malaysia, Malaysia. E-mail: azjsadr@gmail.com
}

Received: September 22, 2014 Accepted: October 27, 2014 Online Published: April 2, 2015

doi:10.5539/ass.v11n9p138

URL: http://dx.doi.org/10.5539/ass.v11n9p138

\begin{abstract}
The major purpose of the present study was to determine the relationship between home environment and emergent literacy among 90 children ( 40 boys and 50 girls) aged 3 to 4 years. Pearson correlation analysis was conducted to examine the relationship between home environment and emergent literacy. The result of this study revealed that home environment had significant relationship with children's emergent literacy.
\end{abstract}

Keywords: home environment, emergent literacy, children

\section{Introduction}

In recent century, literacy deeply affects children's lives and their future (UNESCO, 2005). Therefore, literacy is a vital skill in the new world and a powerful tool for academic, intellectual and personal growth. Emergent literacy skills which are developed prior to five years of age, strongly predict achievement in later literacy learning and many other fields throughout life (Coursin, 2012).

Emergent literacy describes as a continuum of multitude behaviors, skills, methods, and perception about written and language that lead and expand into conventional literacy skills and serve as a basis for future formalized instruction in reading, writing, and spelling (Fischel, Bracken, Fuchs-Eisenberg, Spira, Katz, and Shaller, 2007). In Iran, reading instruction begins in the first grade. Pre-primary education is a one-year programmed for 5 to 6 years old which is not compulsory (Kian, 2010). Only less than $50 \%$ of Iranian children join this program (Mofidi, 2012).

\subsection{Home Environment}

Home is the first place where a child is exposed to a language and has opportunity to observe, discover, and engage in literacy-related activities to explore the development of literacy skills (Lonigan \& Shanahan, 2008). The shortcomings of emergent literacy experiences of preschoolers at home may have been compensated by the frequent drills provided in the first grade for the children. The environment is considered as an integral part of emergent literacy development (Sénéchal, LeFevre, Smith-Chant, \& Colton, 2001; Sénéchal \& LeFevre, 2002; Zill \& Resnick, 2006). Whitehurst \& Lonigan (1998) believed that reading, writing, and oral language may develop in early age when children are exposed to the social contexts in which literacy is an important phenomenon. It has been shown that parents are able to build a home environment that persuades children's learning and communication. Furthermore, the experiences, attitudes, and materials that a child interacts with at home effect on child's home literacy environment (Leseman \& DeJong, 1998; Sénéchal, LeFevre, Thomas, \& Daley, 1998; Whitehurst \& Lonigan, 1998). Exposure to books, magazines, newspapers, and environmental print may influence on children's development of learning to reading (Whitehurst \& Lonigan, 1998). Children with better home literacy environments show higher levels of reading knowledge and skills at kindergarten (Nord, Lennon, Liu \& Chandler, 2000) and primary school (Wade \& Moore, 2000). 


\subsection{Home Environment and Emergent Literacy}

The home environment contributes to young children's emergent literacy, as it is the primary situation in which language and literacy are confronted (Purcell-Gates, 1996). Home environment effects on emergent literacy and language skills because within the home environment children have chances to (a) become familiar with literacy materials, (b) view others who are engaged in literacy activities, (c) investigate literate beliefs individually, (d) engage joint reading and writing behaviors and actions with caregivers, and (e) learn teaching strategies which family members use during joint literacy activities (DeBaryshe, Binder, \& Buell, 2000).

Some researchers studied the relationship between children's home environment and their positive cognitive development (Bradley et al., 1994; Bradley et al., 2001; Linver et al., 2002; Molfese et al., 2003, Leventhal, Martin, \& Brooks-Gunn, 2004). Families whose homes were scored high on the HOME (Caldwell and Bradley, 1984); a measure of the quality and quantity of stimulation and support available within the home setting, had scored higher than families with low scores on the HOME on measures of language skills, cognitive ability, and academic skills through preschool (Bradely et al., 2001). So, the opportunities that parents provided within the home environment have shown to enhance children's emergent literacy (Bennet, Weigel, \& Martin, 2002).

Zhou (1994) examined the relationship between children's emergent literacy achievement and their home literacy activities. Zhou indicated that home literacy were positively associated to children's literacy success. The home literacy direct activities include reading to children, telling stories, and teaching letters, words, or letters had a significant relationship with children's emergent literacy development. The home indirect literacy activities include doing arts and crafts, training children music or songs, doing household chores, visiting a library, visiting an art gallery, museum, or historical place, discussing about family history or ethnic heritage, and connecting children into community or religious events.

Burgess, Hecht, and Lonigan (2002) tried to determine which areas of home literacy environment predict emergent literacy skills. The active home literacy environment was used to measure the amount of child television viewing and the age of initiation of joint reading. The passive home literacy environment was assessed how often the children detected the parents' reading, amount of parent television viewing, and the actual amount of parental reading. The overall home literacy environment was measured by combining questions from the interactive and limiting environment assessments. Results of this study indicated that the active home literacy environment was significant predictor of emergent literacy skills.

Burgess (2002) examined the link between the growing of phonological sensitivity, speech perception, oral language, and other elements of emergent literacy in four and five years old children. In this study, family social class, parents' beliefs and attitudes about spending their money, as well as home literacy environment were measured. Burgess found that home literacy atmosphere was the only predictor of phonological sensitivity progress in children. This study did not examine whether the family social factors, parental attitudes, and traditional variables included in the home literacy environment assessment, or a combination of those factors were responsible for the substantial consequences.

Welsch et al. (2003) divided emergent literacy into three points of reference including outcome based, process-orientated, and developmental orientations. These points of reference have been used to study and characterize the importance of children's emergent literacy skills (Welsch et al., 2003). According to Welsch et al. outcome based may describe the relationships between emergent literacy and later literacy success. Process-oriented describes the associations between social, cognitive, and cultural procedures that mediate children's early success in literacy (Welsch et al., 2003). Welsch et al. (2003) described emergent literacy as a broad theoretical framework in which children's pre-conventional reading and writing behaviors developed mainly during home and school experiences with oral and written language, and it was observed as the foundation of later conventional literacy skills.

Haney and Hill (2004) in a study examined children's vocabulary, alphabet knowledge, and conventions of print. Haney and Hill concluded that the type of direct literacy instruction affected the children's emergent literacy skills. It means that children who received direct instruction on letter sounds involved in other non-formal home literacy activities that may contribute to the higher scores on the vocabulary test. The home literacy environment is a complex system includes both formal and informal components (Sénéchal et al., 1998). As a result, the home literacy environment is a complex system that should be assessed from a broader perspective.

Ayatollahzade (2004) investigated emerging literacy development in young Iranian children. Elements of Iranian children's activities at home, Iranian literacy tools at home, and literacy experiences of Iranian children were examined. The participants were 48 children ages 2 to 3 years. A model of emergent literacy in Iranian family was suggested, which include of Literacy Activities, Verbal Interaction, Environmental Print, and Literacy Tools. 
Ayatollahzade specified that Iranian young children participated in a variety of emergent literacy activities at home, most of which were verbal in nature. Presentation to written and spoken Arabic and literacy activities in religious contexts were unrivaled aspects of emergent literacy in Iran. Iranian homes prepared children with very limited experience to print. The limited writing exposure was through fixed environment print elements which were not directly handled by children. Children's books, storybook reading, and joint book reading were not found to be daily experiences of Iranian children, and this might delay the development of some early literacy skills.

Roberts, Jurgens, and Burchinal (2005) investigated the activities of home literacy among African-American mothers with children aged 3 to 5 year old. This study examined four measurements of home literacy practices include of the shared reading storybook, techniques of maternal reading book, enjoying reading book, and maternal sensitivity. Also, a general measure of the quality of the home environment during pre-school years was applied in order to predict language and emergent literacy skills. The Home Observation for Measurement of the Environment Inventory (HOME; Caldwell \&Bradley, 1984) was also carried out annually. After controlling for maternal education, maternal reading skills, and the child's gender, home literacy practices showed significant correlations with the language and literacy development. Roberts, Jurgens, and Burchinal found that home environment may contribute to the children's language and early literacy skills. Findings of this study revealed that the quality of the home environment predicted the later reading progress of children.

Weigel, Martin, and Bennett (2005) examined the relation between parental reading habits (e.g. parents' reading enjoyment, time spent reading for leisure) and emergent literacy skills among preschool children. Based on ecological perspective, this study indicated that the children's community and environment have a direct influence on literacy development. Results of this study demonstrated that parents were less prepared and conscious during shared-reading practices; rather than, child-care professionals who were more likely attentive and took a more directive view when interacting and reading with young children. Findings also suggested that literacy skills in preschool children affected by combination of both home and child-care literacy experiences. However, this study was measured only language skills not all variety of measures, such as phonemic awareness, letter knowledge, book knowledge, and expressive language.

In addition, Foster, Lambert, Abott-Shim, McCarty, and Franze (2005) examined a broader scope of home literacy environment. In this study four variables were related with the home literacy environment to examine emergent literacy in a group of children enrolled at Head Start. Regularity of reading to the child in the past week, enrichment experience (trips to the library, museum, etc.) in the past month, home learning activities (teaching a song, art projects, etc.) in the past week, and books and other reading materials available at home assessments completed by the parents. Results of this study confirmed that home literacy environment, as well as family social risk, mediated the relationship between socioeconomic status and emergent literacy skills in children. This study considered four elements of home literacy environment however the current studies didn't examine home environment by HOME observation scale (Cadwel \& Bradly, 2003) which is a best known measurement on home environment.

Wu (2007) in a study revealed that Taiwanese mothers teach their children during various kinds of home experiences. These teaching skills could differ from oral language teaching during activities such as cooking, doing house tasks, shopping, to other aspects of structured reading and writing instruction at home. Taiwanese children's early literacy experiences might be received from culturally specific activities such as interaction with family relatives or peers in the society.

Research shows that the experiences children have before formal schooling largely impact development of emergent literacy skills. It has been established that the home is where children first encounter language and literacy and begin to participate in activities that foster their literacy development (DeBaryshe, Binder, \& Buell, 2000). The home environment of young children also has a strong impact on emergent literacy outcomes (DeBaryshe et al., 2000). Much of these research (Sénéchal, LeFevre, Thomas, \& Daley, 1998; Zhou, 1994; Welsch et al., 2003; Edwards, 2007) have focused on home literacy activities that have been shown to be "consequential" to successful acquisition of literacy skills, but they didn't examine home environment by HOME inventories (Caldwell \& Bradly, 2003). As a result, Learning in the home starts from birth; however, families differ in their attitudes toward their responsibility for supporting their children's literacy development and their enthusiasm. Previous studies recommended that parents play an essential position in forming their children's learning environment by selecting appropriate activities, reading materials, and toys (Baker \& Scher, 2002; Rogoff, 1998). 


\section{Method}

\subsection{Location and Respondents}

This study was conducted in Kerman city, the capital and largest city of the Kerman province. Kerman is placed in the south-east of Iran, with a population of 621,374 (Iran census Bureau, 2011). The sample of this study consists of children aged between 3 to 4 years old. According to census of Kerman city (2011), the number of children from birth to 4 years old was 107,885, which only 8589 of them attend in kindergartens (Bureau of welfare organization Iran, 2011).

\subsection{Procedures}

The sample of this survey consisted of 2146 children age 3-4 years old and their mothers (Table 1). In the first step 14 kindergartens have been selected out of four districts by conducting the cluster method. A consent letter was sent to 283 parents and only 188 of them agreed to participate in this survey. Then 96 family was selected randomly from 188, and 6 pairs were deleted from this survey due to incompatible age range.

\subsection{Measures}

Home Environment: The Early Childhood Home Inventory (HOME; Caldwell \& Bradley, 2003) and its 55 items were used to measure the influence of the home environment in a child's cognitive, language, and literacy development. This checklist provides general characteristics of the home environment including responsiveness, sensitivity, acceptance of the child's behavior by parents, structure of environment, provision of positive and caring environment, along with stimulating toys, materials and interactions (See Appendix D). The eight subcategories of HOME were measured: (1) Learning Materials (e.g., child has at least ten children's books), (2) Language Stimulation (e.g., Child is encouraged to learn the alphabet), (3) Physical Environmental(e.g., Building appears safe and free of hazards), (4) Responsively(e.g., Parent holds child close 10-15 minutes per day), (5)Academic Stimulation (e.g., Child is encouraged to learn colors), (6) Modeling (e.g., TV is used judiciously), (7) Variety (e.g., Child has real or toy musical instrument), and (8)Acceptance (e.g., No more than one instance of physical punishment occurred during the past week). The Cranach's alpha coefficient for the HOME total scores was .90 .

Emergent Literacy Assessments: In order to examine emergent literacy, the Language and Emerging Literacy Assessment (LELA; Cunningham, Hicks, \& Williams, 2002) was used. Alphabet Recognition, Book Knowledge, Expressive Language, Beginning Sounds, and Phonemic Awareness are included in this scale. There are upper case and lower case letters in Alphabet Recognition scale as two templates in a random order. The researcher asked the child to show name the letters that are known. Some information about the books is involved in the book knowledge scale. Child must response about his or her favorite book The Expressive Language scale contains five items in which asked the child to retell the story that their teacher read to them several times. Specifically, the teacher listens to discover whether the child has a sense of the story or he or she doesn't influence by the beginning, characters, setting, sequence, and the ending. How children match the beginning sounds is the aim of the Beginning Sounds scale which was assessed by eight items. The Phonemic Awareness scale was measured phonological awareness, the ability to recognize the separate sounds of language. While the child was sitting next to her/his teacher in a private playroom or classroom in the kindergarten, the researcher administered the Language and Emergent Literacy assessments with the child's teacher.

\section{Data Analysis}

A descriptive statistics (mean, standard deviation, minimum and maximum) were utilized to describe the respondents' background (personal and family characteristics) and the key study variables. A Pearson correlation analysis was conducted to examine the relationship between the dependent variable (Emergent Literacy) and independent variable (Home Environment).

\section{Results and Discussion}

\subsection{Descriptive Findings}

More than half (53.3\%) of the respondents were girls. The respondents' age ranged from 3 to 4 years old. The majority $(60 \%)$ of children were first born. Less than half $(15.50 \%)$ of the respondents' fathers were below 30 years old. About $44 \%$ of fathers had bachelor degree. Regarding father's occupation, all (100\%) were employed. In terms of father income, majority (87.9\%) of the fathers were in medium income category ( $\$ 800$ per months). Only $11 \%$ of families were in low income category. According to Raghfar, Khoshdast, and Yazdanpanah (2012), the poverty line in Iran was $\$ 800$ (800,000 Toman) per month for a family with four members. In terms of mother's age $84.50 \%$ of mothers were more than 30 years old. Majority (55.60\%) of the respondents' mothers had bachelor 
degree. However, more than half (65.60\%) of the mothers were unemployed. According to census of Iran (2011) only $13.7 \%$ of women were employed. As shown in Table 1 , more than half $(56.7 \%)$ of the respondents had lower total scores in home environment. In terms of children scores in emergent literacy, more than half $(52.2 \%)$ of children indicated low emergent literacy.

Table 1. Respondent's levels of variables

\begin{tabular}{|c|c|c|c|c|c|c|}
\hline Variables & $\mathrm{N}$ & $\%$ & Min & Max & Mean & S.D \\
\hline Total Home Environment & & & 14 & 54 & 41.21 & 8.830 \\
\hline Low $($ scores $<41.21)$ & 51 & 56.7 & & & & \\
\hline High $($ scores $>41.21)$ & 39 & 43.3 & & & & \\
\hline Total Emergent Literacy & & & 6 & 29 & 19.36 & 4.918 \\
\hline Low $($ scores $<19.36)$ & 47 & 52.2 & & & & \\
\hline High (scores>19.36) & 43 & 47.8 & & & & \\
\hline
\end{tabular}

\subsection{Bivariate Findings}

Pearson correlation was used to determine the relationship between home environment and emergent literacy skills. As Table 2 shows, there is significant relationship between home environment and emergent literacy $(\mathrm{r}=.48, p \leq 0.001)$. This means that respondents, who have high home environment scores, have high literacy skills. The present finding support past studies (Sénéchal \& LeFevre, 2002; Purcell-Gates, 1996; Burgess, Hecht, \& Lonigan, 2002; Hirst \& Di Cristo, 1998; Sénéchal, LeFevre, Thomas, \& Daley, 1998; Haney \& Hill, 2004) that confirmed the significant and positive relationship between home environment and emergent literacy. There are some reasons for the relationship between home environment and emergent literacy. First, the home environment is contributed to young children's emergent literacy, as it is the primary situation in which language and literacy are confronted (Purcell-Gates, 1996). Home is typically the first place in which a child is exposed to language and has the chance to observe, discover, and engage in literacy-related activities (Bracken \& Fischel, 2008; DeBaryshe et al., 2000). Second, parents provide the better quality of home environment including toys, books, and games to facilitate learning literacy in childhood (DeBaryshe, Binder, \& Buell, 2000; Hood, Conlon, \& Andrews, 2008; Korat, 2009). Furthermore, the physical environment as safe, sufficiently roomy, and perceptually appealing may related to mothers' tendency to encourage their child acquiring early literacy skill related to emergent literacy skills (Caldwell \& Bradley, 1984).

Table 2. Relationship between home environment and emergent literacy

\begin{tabular}{cc}
\hline Variables & $r$ \\
\hline Home Environment & $.483 * *$ \\
\hline
\end{tabular}

\section{Conclusion}

Present study aimed to examine the relationship between home environment and emergent literacy among Iranian children. This study found that there was a significant relationship between home environment and emergent literacy. This means that positive home environment which is facilitated by highly involved parent has an important factor in emergent literacy skills of young children. Consequently, Iranian families may need to facilitate their home environment by providing a greater numbers of awareness on knowledge related to emergent literacy activities for their children. As the child grows up in a conducive home environment, the way in which he or she thinks about the world around themselves can be positively enhanced. Growing up in a rich literacy environment may lead children to take hold of literacy skills. In contrast, children in an environment without any value of literacy may fail to realize the importance of literacy then.

So, it is important to consider positive and stimulating home environment characteristics because the home is typically the first place in which a child is exposed to many life experiences. According to Vygotsky social cultural theory (1978), the quality of the adult-child interaction and home environment have a powerful influence 
on the development of child's emergent literacy skills. Vygotsky (1978) also stressed the importance of the multidimensional role of the adults in the home environment.

Home environments may influence on the relationships between parents and their young children literacy. Parents may supply a library area for example in the child's bedroom. They can talk about the environmental print such as signs and food labels, read them with the child, and visit libraries and/or bookstores regularly. Comfortable places and sufficient lighting are also important physical resources. A basket of books in each room is helpful and excite children's literacy. Parents can join art, dramatic play, field trips, music, and singing to the literature that may contribute to their children. While involving interventions that planned to increase quality of home environment, may positively influence children levels of emergent literacy. If quality of the home literacy environment is developed, researchers can start to clarify the exact activities, resources, and contextual factors that are necessary for successful literacy achievement.

\section{Implication}

The findings of this study will be beneficent for parents, educators, and developmental psychologists. The result of this study is significant for professionals to better realize the factors which may have important impact on emergent literacy. The results of this study propose that parent and home environment play a unique and vital role in children's emergent literacy. The finding in this study is also useful for Iranian Ministry of Education, Welfare organization, NGOs in order to promote the language and literacy skills of preschool-age children. Researchers, educators, parents, and policy makers need to consider planning, implementing and evaluating programs for children's emergent literacy.

For developing early literacy in Iran, the government should participate and cooperate in investment and funding programs that are deemed beneficial in nurturing interest and emphasis in the area government should give more attentions and supports to train childhood educators so that they can provide appropriate programs for children. In order to achieve an influential imputes on emergent literacy of children and enduring educational success, workshops, conferences and seminars for parents and educators should be organized by government and relevant organizations.

The present results have significant recommendation for future research and practice. This research is limited home environment and children emergent literacy. Many relevant factors can affect emergent literacy. Future studies are needed to examine other factors such as the impact of parenting style, self-efficacy, emotional intelligence, self-esteem, self-control of mothers. This study was conduct in Kerman, hence, to generalize the results of this study to the other population it is suggested to carry out studies in different locations of the country. The present study was carried out among 90 children aged between 3 to 4 years old. It is recommended that future studies investigate larger samples from different age of groups. This study was a cross-sectional design, so a longitudinal study is needed to clarify the relationship between home environment and emergent literacy.

There are a few limitations related with this study. First, the sample of this study involved children aged 3 to 4 years old live in Kerman. This study has not excluded those children, who live in rural areas, or speak non-standard Farsi dialect, Arabic, Turkish or Kurdish and children who speak in particular regions of Iran. Therefore, the results cannot be generalized beyond this population. Second, another limitation relates to the lack of literature in Iran that could support the result of this study.

\section{References}

Ayatollahzadeh, M. (2004). What is the Nature of Emergent Literacy in Iran? (Doctoral dissertation). Indiana State University.

Baker, L., \& Scher, D. (2002). Beginning readers 'motivation for reading in relation to parental beliefs and home reading experiences. Reading Psychology, 23(4), 239-269. http://dx.doi.org/10.1080/713775283

Bennett, K. K., Weigel, D. J., \& Martin, S. S. (2002). Children's acquisition of early literacy skills: Examining family contributions. Early Childhood Research Quarterly, 17(3), 295-317. http://dx.doi.org/10.1016/ S0885-2006(02)00166-7

Bradley, R. H., Corwyn, R. F., McAdoo, H. P., \& García Coll, C. (2001). The home environments of children in the United States part I: Variations by age, ethnicity, and poverty status. Child Development, 72(6), 1844-1867. http://dx.doi.org/10.1111/1467-8624.t01-1-00382

Bradley, R. H., Whiteside, L., Mundfrom, D. J., Casey, P. H., Kelleher, K. J., \& Pope, S. K. (1994). Early indications of resilience and their relation to experiences in the home environments of low birthweight, 
premature children living in poverty. Child Development, 65(2), 346-360. http://dx.doi.org/10.2307/ 1131388

Bureau of Welfare Organization Iran. (2011). Retrieved from http://www.behzisti.ir/

Burgess, R. G. (2002). In the field: An Introduction to Field Research (Vol. 8). Psychology Press.

Burgess, S. R., Hecht, S. A., \& Lonigan, C. J. (2002). Relations of the home literacy environment (HLE) to the development of reading-related abilities: A one-year longitudinal study. Reading Research Quarterly, 37(4), 408-426. http://dx.doi.org/10.1598/RRQ.37.4.4

Caldwell, B. M., \& Bradley, R. H. (1984). Home Observation for Measurement of the Environment. Little Rock: University of Arkansas at Little Rock.

Caldwell, B. M., \& Bradley, R. H. (2003). HOME Inventory Administration Manual. University of Arkansas for Medical Sciences.

Coursin, A. (2012). Understanding the Development of Alphabet Knowledge in At-Risk Populations: The Influence of Pre-Literacy Skills (Doctoral dissertation). Wisconsin, Milwaukee University.

DeBaryshe, B. D., Binder, J. C., \& Buell, M. J. (2000). Mothers' implicit theories of early literacy instruction: Implications for children's reading and writing. Early Child Development and Care, 160(1), 119-131. http://dx.doi.org/10.1080/0030443001600111

Edwards, C. M. (2007). The Relationship Between Parental Literacy and Language Practices and Beliefs and Toddlers' Emergent Literacy Skills (Doctoral dissertation). Tennessee University.

Fischel, J. E., Bracken, S. S., Fuchs-Eisenberg, A., Spira, E. G., Katz, S., \& Shaller, G. (2007). Evaluation of curricular approaches to enhance preschool early literacy skills. Journal of Literacy Research, 39(4), 471-501. http://dx.doi.org/10.1080/10862960701675333

Haney, M., \& Hill, J. (2004). Relationships between parent-teaching activities and emergent literacy in preschool children. Early Child Development and Care, 174(3), 215-228. http://dx.doi.org/10.1080/030044303200 0153543

Hirst, D., \& Di Cristo, A. (Eds.). (1998). Intonation Systems: a Survey of Twenty Languages. Cambridge University Press.

Hood, M., Conlon, E., \& Andrews, G. (2008). Preschool home literacy practices and children's literacy development: A longitudinal analysis. Journal of Educational Psychology, 100(2), 252. http://dx.doi.org/10.1037/0022-0663.100.2.252

Iran census Bureau. (2011). Retrieved from http://www.amar.org.ir

Kian, M. (2010). How we can help children for social development? Analytical Learning of Pre-School Journal 13(4). Iran.

Korat, O. (2009). The effects of CD-ROM storybook reading on Israeli children's early literacy as a function of age group and repeated reading. Education and Information Technologies, 14(1), 39-53. http://dx.doi.org/10.1007/s10639-008-9063-y

Leseman, P. P., \& De Jong, P. F. (1998). Home literacy: Opportunity, instruction, cooperation and social-emotional quality predicting early reading achievement. Reading Research Quarterly, 33(3), 294-318. http://dx.doi.org/10.1598/RRQ.33.3.3

Leventhal, T., Martin, A., \& Brooks-Gunn, J. (2004). The EC-HOME across five national data sets in the 3rd to 5th year of life. Parenting, 4(2-3), 161-188. http://dx.doi.org/10.1080/15295192.2004.9681269

Linver, M. R., Brooks-Gunn, J., \& Kohen, D. E. (2002). Family processes as pathways from income to young children's development. Developmental psychology, 38(5), 719. http://dx.doi.org/10.1037/0012-1649. 38.5.719

Lonigan, C. J., \& Shanahan, T. (2010). Developing Early Literacy Skills Things We Know We Know and Things We Know We Don't Know. Educational Researcher, 39(4), 340-346. http://dx.doi.org/10.3102/0013189X1 0369832

Mofidi, F. (2012). Management of Pre-School Centers. Forozeh Publication, Iran.

Molfese, V. J., Modglin, A., \& Molfese, D. L. (2003). The Role of Environment in the Development of Reading Skills A Longitudinal Study of Preschool and School-Age Measures. Journal of Learning Disabilities, 36(1), 
59-67. http://dx.doi.org/10.1177/00222194030360010701

Nord, C. W., Lennon, J., Liu, B., \& Chandler, K. (2000). Home Literacy Activities. National Center for Education Statistics, 2(1), 19.

Purcell-Gates, V. (1996). Stories, coupons, and the TV Guide: Relationships between home literacy experiences and emergent literacy knowledge. Reading Research Quarterly, 31(4), 406-428. http://dx.doi.org/10.1598/RRQ.31.4.4

Raghfar, H., Khoshdast, F., \& Yazdanpanah, M. (2012). Measurement of Income Inequality in Iran, 1984-2010. Social Welfare Quarterly26, 12(45), 275-305.

Rogoff, B. (1990). Apprenticeship in thinking: Cognitive Development in Social Context. Oxford University Press.

Sénéchal, M., \& LeFevre, J. A. (2002). Parental involvement in the development of children's reading skill: A five-year longitudinal study. Child Development, 73(2), 445-460. http://dx.doi.org/10.1111/1467-8624. 00417

Sénéchal, M., LeFevre, J. A., Smith-Chant, B. L., \& Colton, K. V. (2001). On refining theoretical models of emergent literacy the role of empirical evidence. Journal of School Psychology, 39(5), 439-460. http://dx.doi.org/10.1016/S0022-4405(01)00081-4

Sénéchal, M., Lefevre, J. A., Thomas, E. M., \& Daley, K. E. (1998). Differential effects of home literacy experiences on the development of oral and written language. Reading Research Quarterly, 33(1), 96-116. http://dx.doi.org/10.1598/RRQ.33.1.5

United Nations Educational, Scientific and Cultural Organization. (2005). Retrieved from https://en.unesco.org/

Vygotsky, L. S. (1978). Mind in Society: The Development of Higher Psychological Processes. Harvard university press.

Wade, B., \& Moore, M. (2000). A sure start with books. Early Years, 20(2), 39-46. http://dx.doi.org/10.1080/ 0957514000200205

Weigel, D. J., Martin, S. S., \& Bennett, K. K. (2005). Ecological influences of the home and the child-care center on preschool-age children's literacy development. Reading Research Quarterly, 40(2), 204-233. http://dx.doi.org/10.1598/RRQ.40.2.4

Welsch, J. G., Sullivan, A., \& Justice, L. M. (2003). That's my letter!: What preschoolers' name writing representations tell us about emergent literacy knowledge. Journal of Literacy Research, 35(2), 757-776. http://dx.doi.org/10.1207/s15548430j1r3502_4

Whitehurst, G. J., \& Lonigan, C. J. (1998). Child development and emergent literacy. Child Development, 69(3), 848-872. http://dx.doi.org/10.1111/j.1467-8624.1998.tb06247.x

Wu, C. C. (2007). Reading Beliefs and Strategies of Taiwanese Mothers with Preschoolers in Relation to the Children's Emergent Literacy (Doctoral dissertation). Syracuse University.

Zhou, H. (1994). Young children's intrinsic motivation for reading. Age, 20(25), 27.

Zill, N., \& Resnick, G. (2006). Emergent literacy of low-income children in Head Start: Relationships with child and family characteristics, program factors, and classroom quality. Handbook of Early Literacy Research, 2, $347-371$.

\section{Copyrights}

Copyright for this article is retained by the author(s), with first publication rights granted to the journal.

This is an open-access article distributed under the terms and conditions of the Creative Commons Attribution license (http://creativecommons.org/licenses/by/3.0/). 